\title{
Medium, Small and Medium Enterprises and Digital Platforms
}

\section{SITASI}

A new business platform is a must for companies that disrupt new media technology, especially in the Covid 19 era. Anticipating all changes in the competitive climate in the digital era in carrying out corporate transformation programs in line with the implementation of good corporate governance values to avoid verbal harm and the risk of failure the greater one. The analysis focuses on efforts to promote Medium, Small and Medium Enterprises that contribute to improving the Indonesian economy. Social protection programs, such as social assistance, are demand-side interventions in preventing a decline in people's purchasing power with the aim of restoring the purchasing power of the poor and vulnerable to poverty. Entrepreneurs are in dire need of liquidity assistance programs ranging from restructuring, relaxation, and new capital assistance. Based on current conditions, the government must focus more on controlling the Covid-19 pandemic so that confirmed cases can be reduced and give confidence to the public, especially the middle and upper classes, to return to shopping and restore consumption, given Indonesia's growing economic condition. Stimulus of protection and social assistance for businesses can drive consumption growth. 203.9 trillion for social protection during the handling of Covid-19. However, it should be understood that the economic recovery will not be evenly distributed across all sectors.

Empowerment and comprehensive support for small businesses must be one of the government's priorities when carrying out transformation by reorganizing the national economy in an effort to encourage economic growth, prevent recession and the Covid-19 pandemic crisis, and significantly reduce it. The number of micro and informal businesses is so massive that the empowerment of ultra micro businesses such as hawkers and street vendors seems to significantly boost the national economy. This group includes hawkers, street vendors, small stalls, market traders, and food stalls with daily income. In general, they have never been in contact with financial institutions and banks. Social protection programs, such as social assistance, are demand-side interventions in preventing a decline in people's purchasing power with the aim of restoring the purchasing power of the poor and vulnerable to poverty. Entrepreneurs are in dire need of liquidity assistance programs ranging from restructuring, relaxation, and new capital assistance. The rapid penetration of the internet in Indonesia raises hopes for information technology that can empower individuals who have been far from the center of the economy and politics.

Ultra micro and micro entrepreneurs in underdeveloped villages who have difficulty getting capital services from banks can access digital storage services. However, the biggest problem in financing the productive sector is the low productivity of ultra-micro scale businesses. This means that business actors are expected to be able to use the internet to increase productivity, increase the number of products, and increase the variety of businesses. Moreover, 
the use of the internet can help ultra micro and micro businesses to play a bigger role as suppliers in the domestic supply chain so as to reduce the entry of imported goods. One of the efforts to overcome these problems is through business partnerships between macro, small and medium entrepreneurs and related parties. Good relations must continue to be developed, for example with fellow MSMEs, cooperatives, the private sector, stateowned enterprises, regionally owned enterprises, and large businesses. Indonesia is carried out simultaneously by cooperatives, the private sector, and state-owned enterprises and regional-owned enterprises. This is closely related to the dissemination of information to the public. Consumers today are not only passively waiting for information about the desired product, but also actively seek information and even provide comments about a product. Consumers can form communities in cyberspace that can communicate with each other, exchange information, provide comments, and express their wishes. Digitalization has proven to be able to open up inclusiveness and electronification in Indonesia. Digitization and electronification of these services can actually support economic recovery programs, such as the distribution of social assistance and financing for MSMEs.

The digitalization of payment and financing systems has the potential to open financial access for 62.9 million MSMEs and 51\% of the population who have not yet reached banking access. MSMEs need to be continuously encouraged so that they can be integrated into national production systems or global supply chains. This pattern has long been applied in Japan, China and South Korea. Several regions in Indonesia have domestic advantages, such as the wealth of unprocessed marine products, agriculture, plantations, and others. Therefore, MSMEs need to develop these unprocessed products into special products to fill the global market. 


\section{DAFTAR PUSTAKA}

Tayibnapis, A. Z., Wuryaningsih, L. E., \& Gora, R. (2021). Medium, Small and Medium Enterprises and Digital Platforms . South Asian Journal Of Social Studies and Economics 